\title{
5 Pengaruh Efektifitas Absensi Fingerprint Terhadap Kedisiplinan Pegawai \\ (Studi Kasus di Kantor Kementrian Agama Kabupaten Bangka)
}

\author{
Revaldi Agatha \\ agatharevaldi@gmail.com \\ STISIPOL Pahlawan 12
}

\section{ABSTRAK}

Penelitian ini bertujuan untuk melihat pengaruh efektivitas absensi finger print terhadap kedisiplinan pegawai. Penelitian ini membahas tentang pengaruh absensi finger print terhadap kedisiplinan pegawai. Penelitian ini dilatarbelakangi oleh adanya masalah dari tingkat ketepatan waktu pegawai saat masuk dan pulang kerja sehingga menjadi fenomena yang menarik untuk diteliti.Rumusan masalah penelitian ini adalah apakah efektivitas absensi finger print berpengaruh terhadap kedisiplinan pegawai. Tujuan penelitian ini adalah untuk mengetahui apakah efektivitas absensi finger print yang ada di kantor berpengaruh terhadap kedisiplinan pegawai. Jenis penelitian ini adalah kuantitatif asosiatif dengan menggunakan metode sensus. Subjek dan lokasi penelitian adalah 56 orang pegawai Kantor Kementerian Agama Kabupaten Bangka. Metode analisis data yang digunakan adalah regresi linearitas sederhana dengan teknik pengumpulan data menggunakan kuesioner dan studi pustaka.

Hasil penelitian dan pembahasan tentang pengaruh efektivitas absensi finger print terhadap kedisiplinan pegawai di Kantor Kementerian Agama Kabupaten Bangka menunjukkan bahwa terdapat pengaruh variabel efektivitas absensi finger print (X) terhadap kedisiplinan pegawai (Y) karena hasil pengujian hipotesis menunjukkan bahwa nilai signifikansi < 0,05 .

Kedisiplinan pegawai dipengaruhi oleh efektivitas absensi finger print memiliki nilai pengaruh yang sangat tinggi, yaitu $66,4 \%$. Harapan peneliti untuk peneliti yang akan datang adalah agar dapat dilakukan penelitian lebih lanjut terhadap indikator lain yang mempengaruhi kedisiplinan pegawai.

Kata kunci: absensi finger print, kedisiplinan

\begin{abstract}
This study aims to look at the effect the effectiveness of finger print attendance on employee discipline. This study discusses the effect of finger print attendance on employee discipline. This research is motivated by the problem in the level of punctuality of employees when entering and returning from work so that it becomes an interesting phenomenon to be studied. The problem's formulation of this study is whether finger print attendance affects employee discipline. The purpose of this study is to find out whether finger print attendance in the office affects employee discipline. This type of research is associative quantitative using the census method. The subject and location of the study were 56 people in the office of the ministry of religion in Bangka Regency. The data analysis method used is simple linearity regression with data collection techniques using a questionnaire and literature study.

The results of this study and the discussion about the effect of the effectiveness of finger print attendance on employee discipline at the Kantor Agama Kabupaten Bangka, that there is an effect of the finger print attendance (X) effectivity variable on employee discipline $(Y)$ because the results of hypothesis testing indicate that the significance value $<0.05$. Employee discipline is influenced by the effectiveness of finger print attendance and has a very high influence value of 66.4\%. Researchers for future researchers expect that further research can be done on other indicators that affect employee discipline.
\end{abstract}

Keywords: finger print attendance system, discipline 
Efisiensi menjadi dasar penggunaan sistem

\section{PENDAHULUAN}

Perkembangan teknologi membawa dampak pada efisiensi dan efektivitas pekerjaan yang dilakukan. Perkembangan teknologi berpengaruh terhadap instansi, yakni efektivitas kinerja yang dilakukan pegawai instansi tersebut. Perkembangan teknologi bagi instansi juga bisa menghemat pengeluaran dengan digunakannya komputerisasi.

Komputerisasi juga bisa menghemat waktu dan biaya apabila sistem tersebut dapat dijalankan dengan baik. Salah satu contoh sistem komputerisasi adalah absensi finger print yang memiliki keunggulan tidak memerlukan kertas ataupun kartu dalam penggunaannya. Sistem absensi elektronik yang digunakan dalam mengakses absensi hanya memerlukan sidik jari sehingga lebih memudahkan dalam penggunaan. Absensi elektronik juga memudahkan dalam membuat laporan ataupun rekapitulasi absensi tanpa harus memantau sistem absensi pegawai.

Menurut Suyadi (2010: 103), dengan diterapkannya sistem absensi finger print, proses pengambilan informasi kehadiran pegawai menjadi hampir 90\%-95\% akurat karena didasarkan pada sidik jari tiap pegawai. Selain itu, proses pencatatan dan pelaporan dilakukan secara otomatis oleh software khusus. Kesalahan ataupun manipulasi pencatatan dapat dihilangkan dikarenakan minimnya campur tangan pegawai administrasi. Informasi yang akurat mencerminkan kondisi yang sebenarnya sehingga hal ini menjadi landasan pengambilan keputusan serta kebijakan dan kemajuan suatu instansi atau organisasi. identifikasi finger print di sebuah organisasi ataupun instansi. Alat ini mendorong organisasi atau instansi untuk menghemat waktu, tenaga, sekaligus keamanan. Dengan adanya absensi finger print, bukti kehadiran pegawai bisa didapatkan secara akurat. Tentu hal ini sangat membantu dalam meningkatkan kedisiplinan pegawai, khususnya bagian sumber daya manusia tatkala mengevaluasi kinerja pegawai.

Absensi finger print merupakan alat bantu dalam meningkatkan kedisiplinan para pegawai yang ada pada suatu instansi. Menurut Afandi (2018: 12), disiplin pada dasarnya tindakan manajemen untuk mendorong agar para anggota organisasi dapat memenuhi berbagai ketentuan dan panduan yang berlaku dalam suatu organisasi atau instansi.

Disiplin memiliki pengaruh yang besar dalam meningkatkan kinerja pegawai. Disiplin sebagai suatu proses yang dapat menumbuhkan perasaan seseorang untuk mempertahankan dan meningkatkan tujuan organisasi melalui kepatuhan menjalankan peraturan organisasi.

Disiplin kerja juga dapat dikatakan baik apabila memenuhi syarat, di antaranya adalah datang dan pulang sesuai dengan peraturan, tidak meninggalkan kantor tanpa izin, serta menaati peraturan yang telah ditetapkan, baik tertulis maupun tidak tertulis.

Menurut Bintoro dan Daryanto (2017: 95), disiplin juga dapat dijadikan sebagai proses latihan pegawai agar dapat mengembangkan kontrol diri dan bekerja lebih efektif. Kedisiplinan merupakan aspek penting yang harus dimiliki oleh seluruh pegawai karena dengan adanya kedisiplinan 
seluruh aktivitas pegawai dapat menjadi lebih teratur dan terarah.

Disiplin menunjukkan suatu kondisi atau sikap hormat yang ada pada diri pegawai terhadap peraturan yang berlaku. Disiplin meliputi ketaatan dan hormat terhadap perjanjian yang dibuat antara pegawai dengan instansi atau organisasi tempat pegawai bekerja. Disiplin berkaitan erat dengan sanksi yang dapat dijatuhkan kepada pegawai yang melanggar peraturan yang telah ditetapkan.

Kedisiplinan pegawai dapat memaksimalkan kinerja pegawai dengan cara mencegah pemborosan waktu. Disiplin juga dapat mencegah waktu mulai kerja yang lambat atau terlalu awal mengakhiri kerja yang disebabkan oleh keterlambatan atau kemalasan.

Hasil dari peningkatan kedisiplinan setelah menggunakan absensi finger print sangat diharapkan oleh setiap instansi, khususnya di Kantor Kementerian Agama Kabupaten Bangka. Penerapan absensi finger print juga diharapkan dapat memotivasi pegawai untuk bekerja lebih baik dan memberikan kontribusi yang terbaik kepada organisasi atau instansi.

Pada Peraturan Menteri Agama Nomor 28 Tahun 2013 tentang disiplin kehadiran Pegawai Negeri Sipil di lingkungan Kementerian Agama, pasal 2 menyebutkan bahwa hari kerja di lingkungan Kementerian Agama Kabupaten Bangka ditetapkan lima hari kerja per minggu, mulai Senin sampai Jumat atau sesuai dengan ketentuan hari kerja pemerintah daerah.

Sanksi pelanggaran diatur pada pasal 12 yang berbunyi: "PNS yang tidak memenuhi kehadiran dikenakan sanksi sesuai dengan ketentuan peraturan perundang-undangan. Kehadiran sebagaimana dimaksud diperhitungkan dalam pemberian tunjangan uang makan 1 bulan."

Disebutkan dalam informasi yang ditampilkan pada situs resmi Kementerian Agama RI (19/11/2015/09:14:28): “Pada tahun 2012 yang lalu Kantor Kementerian Agama Kabupaten Bangka sudah mulai menerapkan absensi pegawai dengan menggunakan finger print (sidik jari). Akan tetapi, ada pegawai yang melakukan kecurangan dengan mengotak-atik absensi. Jadi, pada saat absensi sidik jari akan direkap terjadi temuan ada oknum PNS yang sudah absen pulang padahal waktu pulang belum tiba. Begitu juga ketika jam istirahat masih ada oknum pegawai yang telat masuk kembali ketika usai istirahat."

Dalam meningkatkan citra, kerja, dan kinerja instansi atau organisasi menuju ke arah profesionalisme dan menunjang terciptanya lingkungan kerja yang baik, diperlukan adanya penyatuan arah dan pandangan bagi pegawai. Hal ini untuk dipergunakan sebagai pedoman atau acuan dalam melaksanakan tugas, baik manajerial maupun operasional, di seluruh bidang tugas dan unit organisasi instansi secara terpadu. Selain itu, pendisiplinan pegawai sangat perlu untuk meningkatkan citra, kerja, dan kinerja pegawai.

Pendisiplinan dilakukan untuk menanamkan ataupun memaksakan nilai-nilai agar subjek memiliki kemampuan menaati peraturan. Akan tetapi, pada kenyataannya masih ada oknum pegawai yang melakukan pelanggaran ataupun kecurangan.

Sejumlah permasalahan yang dihadapi oleh birokrasi Indonesia, salah satunya berkenaan dengan sumber daya manusia. Sumber daya manusia yang dimaksud adalah pegawai negeri 
sipil yang ditempatkan dan bekerja di lingkungan birokrasi untuk menjalankan tugas pokok dan fungsi sebagaimana yang telah ditetapkan. Permasalahan SDM antara lain berupa besarnya jumlah PNS dan tingkat pertumbuhan yang tinggi dari tahun ke tahun, rendahnya kualitas dan ketidaksesuaian kompetensi yang dimiliki, kesalahan penempatan dan ketidakjelasan jalur karier yang dapat ditempuh.

Menurut Gie (dalam Moenir, 2014: 42), dalam praktik secara umum, pegawai negeri Indonesia masih banyak kekurangan, yaitu kurang mematuhi peraturan kedisiplinan pegawai sehingga dapat menghambat kelancaran pemerintahan dan pembangunan nasional, antara lain adalah masih adanya jiwa kepegawaian dengan berpikir mengikuti kebiasaan bagian, bukan terletak pada kesatuan yang harmonis melainkan kesatuan pada bagian-bagian tersendiri, mempunyai bentuk dan corak yang berbeda, serta kurang menghargai ketepatan waktu.

Itulah kenyataan yang terjadi meskipun sudah ada peraturan perundang-undangan yang mengatur secara khusus mengenai Kode Etik PNS maupun mengenai hak dan kewajiban PNS. Akan tetapi, PNS yang berdaya guna dan efektif masih sangat jauh dari harapan. Banyaknya keluhan yang datang dari masyarakat menunjukkan masih adanya berbagai keterbatasan pada aparatur pemerintahan. Sering terdengar keluhan masyarakat terutama tentang pelayanan para aparat pemerintahan. Berbagai keluhan terkait kelambatan pelayanan tidak hanya disebabkan oleh kuantitas maupun kualitas aparatur tapi juga disebabkan oleh masalah kedisiplinan.

Yang memprihatinkan, ketidakdisiplinan dalam bekerja itu dilakukan oleh hampir semua tingkatan PNS. Mulai dari pegawai bawah sampai para pejabat tinggi; mulai dari hal-hal yang kecil sampai hal-hal yang besar dan prinsip. Kedudukan sebagai abdi masyarakat dan juga abdi negara sepertinya sudah terlupakan.

Salah satu indikasi rendahnya kualitas PNS tersebut adalah adanya pelanggaran disiplin. Untuk meningkatkan kedisiplinan PNS, pemerintah pusat sebenarnya telah membuat regulasi berupa Peraturan Pemerintah Nomor 53 Tahun 2010 tentang Disiplin Pegawai Negeri Sipil. Ketentuan pelaksanaan Peraturan Pemerintah Nomor 53 tersebut ditetapkan dalam Surat Edaran Kepala Badan Administrasi Kepegawaian Negara Nomor 21 Tahun 2010. Peraturan Disiplin Pegawai Negeri Sipil yang dimaksud adalah peraturan yang mengatur kewajiban, larangan, dan sanksi apabila kewajiban tidak ditaati atau dilanggar oleh pegawai negeri sipil. Dengan maksud untuk mendidik dan membina pegawai negeri sipil, mereka yang melakukan pelanggaran atas kewajiban dan larangan dikenakan sanksi berupa hukuman disiplin. Karena itu, timbullah kewajiban dan hak setiap pegawai negeri sipil. Salah satu kewajibannya adalah setiap pegawai negeri wajib menaati peraturan jam bekerja dan tata tertib pekerjaan. Peraturan jam bekerja ditetapkan oleh menteri yang diserahi urusan pegawai, sedangkan tata tertib pekerjaan diatur dengan keputusan menteri yang bersangkutan.

Dalam kenyataannya, tampaknya lebih banyak pegawai negeri yang kurang disiplin dalam bekerja, terutama dalam disiplin waktu bekerja, semisal keterlambatan datang hingga mangkir dari kewajiban bekerja. Contoh semacam ini dijumpai di Kantor Kementerian Agama Kabupaten Bangka. Ada oknum pegawai yang melakukan pelanggaran 
kedisiplinan jam kerja walaupun sudah diterapkan absensi finger print. Padahal, adanya absensi finger print seharusnya menjadikan para pegawai bisa termotivasi untuk datang tidak terlambat dan lebih rajin untuk datang ke kantor mengingat absensi dengan sistem ini relatif aman dari manipulasi.

Dalam rangka meningkatkan disiplin pegawai, Kantor Kementerian Agama Kabupaten Bangka menerapkan absensi finger print. Penerapan absensi finger print dilakukan agar memudahkan atasan untuk melihat tingkat kedisiplinan tiap-tiap pegawai. Pada sistem absensi manual, atasan atau pegawai lain tidak bisa melihat tingkat kedisiplinan pegawai.Pada sistem absensi manual tidak ada keterangan kapan pegawai tersebut datang dan pulang sesuai jam kerja instansi. Tidak menutup kemungkinan ada oknum pegawai yang tidak bertanggung jawab, misalnya sengaja tidak masuk kantor tapi dia tampak hadir di kantor. Caranya adalah dengan menghimpun beberapa hari kerja seraya menitipkan absensi pada pegawai lain.

Walaupun diperkirakan aman dan adil, ternyata sistem absensi finger print tidak sepenuhnya sempurna. Dalam pelaksanaan absensi finger print di Kantor Kementerian Agama Kabupaten Bangka pada tahun 2016, misalnya, ada pegawai yang mengeluh karena merasa dicurangi. Pasalnya, pegawai itu selalu hadir pukul 07.00 tapi dalam hasil rekapitulasi absensi finger print kedatangan jam kerjanya berubah menjadi pukul 09.00 sehingga dinyatakan datang terlambat. Dalam kasus semacam ini ditengarai terjadi maladministrasi. Diduga ada oknum yang tidak bertanggung jawab, yakni melakukan kecurangan dengan mengotak-atik absensi finger print. Dalam kasus ini terjadi ketidakjujuran (dishonesty) tindakan yang dilakukan oleh oknum pegawai yang tidak bertanggung jawab dan mementingkan kepentingan pribadi. Akibat tindakan tidak jujur itu, oknum tersebut merugikan para pegawai yang lain. Dengan mengotak-atik absensi finger print, data pemantauan kedisiplinan pegawai menjadi tidak sesuai lagi dengan data yang sebenarnya sehingga terjadi kasus ada pegawai yang dinyatakan terlambat terus-menerus walaupun sebenarnya dia datang sesuai waktu.

Pada tahun 2015 pegawai yang hadir ataupun masuk kerja sebanyak 7311 kali, pegawai yang tidak masuk kerja tanpa keterangan sebanyak 17 kali, pegawai yang cuti sebanyak 159 kali, pegawai yang dinas luar sebanyak 755 kali, pegawai yang datang terlambat dan pulang terlambat sebanyak 9845 kali. Jumlah keseluruhan data yang terekam pada tahun 2015 adalah 18087.

Pada tahun 2016 pegawai yang hadir sebanyak 7800 kali, pegawai yang tidak hadir sebanyak 0 kali, pegawai yang cuti sebanyak 187 kali, pegawai yang dinas luar sebanyak 1094, pegawai yang terlambat datang dan terlambat pulang sebanyak 10549 kali. Jumlah keseluruhan data yang terekam pada tahun 2016 adalah 19630 kali.

Pada tahun 2017 pegawai yang hadir sebanyak 8627 kali, pegawai yang tidak hadir sebanyak 0 kali, pegawai yang cuti sebanyak 275 kali, pegawai yang dinas luar sebanyak 1140 kali, pegawai yang datang terlambat dan pulang terlambat sebanyak 11873 kali. Jumlah keseluruhan data yang terekam pada tahun 2017 adalah 21915 kali.

Dari uraian di atas dapat diketahui bahwa pegawai pada tahun 2015 yang tidak hadir 
sebanyak 17 kali, pegawai yang tidak hadir pada tahun 2016 sebanyak 0 kali, dan pegawai yang tidak hadir pada tahun 2017 sebanyak 0 kali. Dari data tersebut, pegawai yang tidak hadir mengalami penurunan dari tahun 2015 yang ketidakhadirannya 17 kali menjadi 0 atau tidak ada pegawai yang tidak hadir pada tahun 2016 dan 2017.

Pegawai yang tidak hadir mengalami penurunan karena pada tahun 2015 diadakan pemeriksaan oleh Dirjen Pusat Kantor Kementerian Agama. Hal tersebut menyebabkan terjadinya penurunan ketidakhadiran pegawai yang ada di Kantor Kementerian Agama Kabupaten Bangka.

Pada penerapan absensi finger print, pegawai yang datang terlambat dan pulang terlambat pada tahun 2015 sebanyak 9845 kali, pegawai yang datang terlambat dan pulang terlambat pada tahun 2016 sebanyak 10549 kali dan pegawai yang datang terlambat dan pulang terlambat pada tahun 2017 sebanyak 11873 kali. Dari data tersebut pegawai yang datang terlambat dan pulang terlambat mengalami peningkatan setiap tahunnya; jarak antara tahun 2015 dan 2016 sebanyak 704 kali, jarak antara tahun 2016 dan 2017 sebanyak 1324 kali.

Dari data tersebut bisa disimpulkan bahwa penerapan kedisiplinan yang ada di Kantor Kementerian Agama Kabupaten Bangka masih belum optimal. Di satu sisi, peneliti menyimpulkan bahwa penerapan absensi finger print di Kantor Kementerian Agama Kabupaten Bangka mampu menurunkan tingkat ketidakhadiran pegawai. Di sisi yang lain, terjadi peningkatan pegawai yang hadir terlambat dan pulang terlambat.

Dari latar belakang di atas, peneliti tertarik untuk melakukan penelitian dengan judul "Pengaruh Efektivitas Absensi Finger Print (Sidik Jari) terhadap Kedisiplinan Pegawai di Kantor Kementerian Agama Kabupaten Bangka.”

\section{Rumusan Masalah}

Rumusan masalah dalam penelitian ini adalah apakah efektivitas absensi finger print berpengaruh terhadap kedisiplinan pegawai di Kantor Kementerian Agama Kabupaten Bangka.

\section{Tujuan Penelitian}

Tujuan yang ingin dicapai dalam penelitian ini adalah untuk mengetahui apakah efektivitas absensi finger print berpengaruh terhadap kedisiplinan pegawai di Kantor Kementerian Agama Kabupaten Bangka.

\section{LANDASAN TEORI}

\section{Efektivitas}

Menurut Affandi (2018: 3), efektivitas adalah suatu kegiatan atau program yang menciptakan suatu kondisi ketika pegawai mampu mencapai produktivitas tinggi.

Menurut Miler (dalam Tangkilisan, 2005: 138), efektivitas adalah suatu tingkatan seberapa jauh suatu sistem sosial mencapai tujuannya.

Menurut Mashun (2006: 182), efektivitas adalah suatu hubungan antara pengeluaran dengan sasaran atau tujuan yang harus dicapai. Pada dasarnya pendapat ini berhubungan dengan pencapaian tujuan atau target kebijakan.

Menurut Affandi (2018: 9), faktor yang mempengaruhi efektivitas adalah kepemimpinan, yaitu seseorang yang mengatur jalannya sebuah operasional dalam sebuah organisasi; (2) kepuasan kerja, yaitu karyawan puas dengan hasil kerja di perusahaan sehingga karyawan akan efektif dalam bekerja; (3) disiplin, yaitu menaati peraturan perusahaan sehingga 
tercipta karyawan yang efektif dalam bekerja; (4) kompetensi, yaitu pengetahuan dan keahlian para karyawan yang akan memperlancar tugasnyatugasnya.

Menurut Tangkilisan (2005: 141), efektivitas merupakan suatu kebijakan yang dilakukan untuk mencapai tujuan yang ingin dicapai. Adapun indikator efektivitas meliputi: (1) pencapaian target, sejauh mana target ataupun suatu tujuan dapat rencanakan oleh sebuah organisasi ataupun instansi yang dapat diwujudkan dengan baik; (2) kemampuan adaptasi, sejauh mana organisasi ataupun instansi dapat menyesuaikan dirinya dengan perubahan yang terjadi, baik itu dari dalam organisasi ataupun dari luar organisasi; (3) kepuasan kerja, sejauh mana kondisi yang dirasakan oleh seluruh anggota organisasi ataupun instansi bisa memberikan kenyamanan dan motivasi bagi peningkatan kinerja pegawai; (4) tanggung jawab, sejauh mana tugas yang dilaksanakan oleh pegawai organisasi ataupun instansi sesuai dengan kesepakatan yang telah ditetapkan.

\section{Absensi Finger Print (Sidik Jari)}

Menurut Kasmir (2016: 204), absensi adalah keberadaan atau bukti kehadiran karyawan pada saat masuk jam kerja sampai dengan pulang kerja.

Menurut Cahyana (dalam Faisal, 2006: 26), absensi adalah pencatatan informasi yang mendalam dan terperinci mengenai kehadiran seorang pegawai dapat menentukan prestasi kerja seseorang, gaji/upah, produktivitas dan kemajuan instansi/lembaga secara umum.

Menurut Suyadi (2010: 103), sidik jari adalah kulit pada telapak tangan atau kaki yang tertutupi garis timbul kecil yang disebut rabung gesekan. Finger Print (sidik jari) mempunyai tingkat akurasi mencapai 90-95\% dan tidak dipengaruhi oleh kondisi apa pun bahkan tidak berubah sepanjang hayat.

Menurut Tofik (2010: 9), finger print adalah teknologi yang menunjang untuk keperluan absensi, yang di dalamnya mencakup pemasukan, penyimpanan data jam masuk dan jam pulang, serta memproses data tersebut menjadi sebuah laporan yang nantinya dapat dipergunakan untuk pengambilan kebijakan-kebijakan yang dilakukan oleh pimpinan.

\section{Disiplin}

Menurut Afandi (2018: 11), disiplin adalah suatu tata tertib atau peraturan yang dibuat oleh manajemen suatu organisasi, disyaratkan oleh dewan komisaris atau pemikiran model, disepakati oleh serikat pekerja dan diketahui oleh dinas tenaga kerja. Pada tahap selanjutnya, orang-orang yang tergabung dalam organisasi tunduk pada tata tertib yang ada dengan perasaan yang tercipta ataupun terbentuk melalui serangkaian proses perilaku yang menunjukkan nilai-nilai ketaatan, kepatuhan, keteraturan, dan tata tertib.

Menurut Hasibuan (2014: 193), disiplin kerja adalah kesadaran dan kesediaan seseorang menaati semua peraturan organisasi ataupun instansi dan norma-norma sosial yang berlaku.

Menurut Sinambela (2017: 334), disiplin kerja adalah kepatuhan pada aturan atau perintah yang telah ditetapkan oleh organisasi ataupun instansi.

Menurut Affandi (2018: 21), disiplin merupakan suatu tata tertib atau aturan yang telah disepakati sebelumnya dan harus dijalankan 
bersama. Berikut ini beberapa indikator disiplin kerja: (1) masuk kerja tepat waktu, yakni pegawai selalu hadir saat waktu kerja tanpa terlambat pada saat datang ataupun pulang kerja; (2) penggunaan waktu secara efektif, yakni kegiatan pegawai yang digunakan dalam memanfaatkan waktu dengan baik tatkala seseorang mampu menyelesaikan sesuatu dengan lebih cepat dan bekerja lebih cerdas; (3) tidak pernah mangkir/tidak bolos kerja, yakni kegiatan atau tindakan yang dilakukan pegawai tanpa bolos ataupun meninggalkan pekerjaan yang sedang dikerjakannya; (4) mematuhi semua peraturan organisasi atau perusahaan, yakni kegiatan ataupun tindakan pegawai yang menjalankan atau melaksanakan suatu pekerjaan sesuai dengan aturan yang telah disepakati bersama; (5) target pekerjaan, yakni rencana yang ingin dicapai oleh organisasi atau instansi dengan pegawai sebagai motor atau penggerak yang menjalankan.

Menurut Afandi (2018: 15), prinsip disiplin terdiri dari: (1) pendisiplinan dilakukan secara pribadi; (2) pendisiplinan harus bersifat membangun; (3) mendisiplinkan haruslah dilakukan oleh atasan langsung dengan segera; (4) keadilan dalam pendisiplinan sangat diperlukan; (5) pimpinan hendaknya tidak seharusnya memberikan pendisiplinan ketika bawahan sedang absen.

Menurut Afandi (2018: 14), fungsi disiplin adalah (1) menata kehidupan bersama dalam suatu organisasi; (2) membangun dan melatih kepribadian yang baik; (3) memaksa anggota untuk mengikuti peraturan organisasi; (4) memberikan sanksi atau hukuman bagi yang melanggar disiplin.

\section{ETODOLOGI}

\section{Jenis Penelitian}

Jenis penelitian ini adalah asosiatif dengan pendekatan kuantitatif. Menurut Husein (2007: 37), penelitian kuantitatif adalah penelitian yang didasarkan pada data yang dapat dihitung untuk menghasilkan penaksiran kuantitatif yang kokoh.

\section{Jenis data}

Penelitian ini menggunakan data kuantitatif berupa angka-angka (numeric). Jenis data yang digunakan adalah data interval. Menurut Kuncoro (2007: 23), data interval adalah data yang diukur dengan jarak di antara dua titik pada skala yang sudah diketahui. Data interval dapat dinyatakan dengan angka 1 sampai dengan 5 dan 7 . Pengukuran ini menggunakan konsep jarak (interval) yang sama (equality interval) karena tidak menggunakan angka 0 (nol) sebagai awal perhitungan dan nilai skala interval bukan angka absolut, misalnya jarak antara 1 dengan 2 sama dengan jarak antara 3 dengan 4.

\section{Sumber Data}

Dalam penelitian ini sumber data dibagi menjadi dua, yaitu sumber data primer dan sumber data sekunder. Menurut Sugiyono (2007: 308), sumber data primer adalah sumber data yang langsung memberikan data kepada pengumpul data. Sumber data primer berasal dari kuesioner yang disebarkan kepada pegawai Kementerian Agama Kabupaten Bangka.

Menurut Sugiyono (2007: 308), sumber data sekunder adalah sumber data yang tidak langsung memberikan data kepada pengumpul data. Sumber data ini berasal dari studi kepustakaan (library research), yakni didapat dengan cara mengumpulkan data melalui literatur, 
artikel, internet, dan sumber bacaan yang relevan serta mendukung pada penelitian ini, selain dokumen dan arsip di Kantor Kementerian Agama Kabupaten Bangka.

\section{Populasi}

Menurut Arikunto (2006: 130), populasi adalah keseluruhan subjek penelitian. Menurut Sugiyono (2012: 115), populasi merupakan wilayah generalisasi yang terdiri atas objek/subjek yang mempunyai kualitas dan karakteristik tertentu dan ditetapkan oleh peneliti untuk dipelajari lalu ditarik kesimpulan.

Dalam penelitian ini, populasi yang dimaksud adalah pegawai di Kantor Kementerian Agama Kabupaten Bangka berjumlah 56 orang. Data yang diperoleh peneliti dengan jumlah populasi 56 orang didapat dari total jumlah keseluruhan pegawai Kementerian Agama Kabupaten Bangka.

\section{Sampel}

Menurut Indranata (2008: 170), sampel adalah sebagian dari seluruh individu yang menjadi objek penelitian. Sampel adalah bagian dari populasi yang dianggap bisa mewakili populasi. Sesuai dengan pengertian ini, dapat diambil kesimpulan bahwa sampel merupakan sebagian dari jumlah dan karakteristik. Yang dimaksud jumlah dan karakteristik dalam penelitian ini adalah sebagian dari pegawai Kantor Kementerian Agama Kabupaten Bangka.

Menurut Arikunto (2006: 112), apabila subjek kurang dari 100, maka lebih baik diambil semuanya sehingga penelitiannya merupakan penelitian populasi dengan menggunakan teknik sensus. Dalam penelitian ini, yang menjadi sasaran adalah seluruh pegawai Kantor Kementerian Agama Kabupaten Bangka yang berjumlah 56 orang.

\section{Teknik dan Instrumen Penelitian}

Teknik dan instrumen penelitian yang digunakan dalam penelitian ini adalah kuesioner dan riset perpustakaan. Menurut Sugiyono (2009: 142), kuesioner merupakan teknik pengumpulan yang dilakukan dengan memberikan pertanyaan kepada subjek penelitian secara tertulis untuk dijawab. Pada penelitian ini peneliti memberikan daftar pertanyaan kepada pegawai di Kantor Kementerian Agama Kabupaten Bangka untuk diisi dan dikembalikan kepada peneliti.

Menurut Ruslan (2006: 31), riset kepustakaan dilakukan untuk mencari data atau informasi riset melalui membaca jurnal ilmiah, buku-buku referensi, dan bahan-bahan publikasi yang tersedia di perpustakaan yang berhubungan dengan penelitian, selain data berupa dokumen dan arsip di Kantor Kementerian Agama Kabupaten Bangka.

\section{Metode Analisis Instrumen Penelitian}

Skala yang digunakan dalam penelitian ini adalah Skala Sikap Model Likert. Menurut Ruslan (2006: 198), Skala Likert dikembangkan oleh Rensis Likert, dan sering disebut sebagai method of summated ratings, yang berarti nilai peringkat setiap jawaban atau tanggapan/sikap itu dijumlahkan sehingga mencapai nilai total. Berikut ini peringkat lima angka penilaian:

Tabel 1. Pedoman Nilai Skala Likert

\begin{tabular}{|l|c|}
\hline \multicolumn{1}{|c|}{ Pilihan Jawaban } & Skala Likert \\
\hline Sangat Tidak Setuju (STS) & 1 \\
\hline Tidak Setuju (TS) & 2 \\
\hline Setuju (S) & 3 \\
\hline
\end{tabular}




\begin{tabular}{|l|c|}
\hline Sangat Setuju (SS) & 4 \\
\hline Sangat Setuju Sekali (SSS) & 5 \\
\hline
\end{tabular}

Sumber: Ruslan (2006: 198)

\section{Uji Validitas}

Menurut Arikunto (2006: 168), validitas adalah suatu ukuran yang menunjukkan pada tingkat-tingkat kevalidan atau kesahihan suatu instrumen. Suatu instrumen yang valid atau sah berarti memiliki validitas rendah. Uji validitas dalam penelitian ini menggunakan analisis butir, yaitu mengorelasikan skor tiap item dengan skor total yang merupakan jumlah dari tiap skor item. Jika ada item yang tidak memenuhi syarat, maka item tersebut tidak akan diteliti lebih lanjut. Uji validitas dalam penelitian ini menggunakan korelasi product moment dengan rumus sebagai berikut:

$$
r x y=\frac{N \cdot \sum x y-\sum x \cdot \sum y}{\sqrt{N \cdot \sum x^{2}-\left(\sum x\right)^{2}} \cdot \sqrt{N \cdot \sum y^{2}-\left(\sum y\right)^{2}}}
$$

$$
\begin{aligned}
& \text { Keterangan: } \\
& \text { rxy }=\text { Koefisien korelasi antar } \mathrm{x} \text { dan } \mathrm{y} \\
& \mathrm{N} \quad=\text { Banyaknya subjek } \\
& \mathrm{x}=\text { Jumlah skor total } \mathrm{x} \\
& \mathrm{y}=\text { Jumlah skor } \mathrm{y} \\
& \mathrm{x}^{2}=\text { Jumlah dari kuadrat } \mathrm{x} \\
& \mathrm{y}^{2}=\text { Jumlah dari kuadrat } \mathrm{y} \\
& \text { xy }=\text { jumlah perkalian antara skor } \mathrm{x} \text { dan skor } \mathrm{y}
\end{aligned}
$$

Menurut Santoso (2005: 274), dasar pengambilan keputusan validitas instrumen penelitian adalah sebagai berikut:
Jika $r$ hitung positif, serta $r$ hitung $>r$ tabel, maka butir tersebut valid.

Jika $r$ hitung positif, $r$ hitung $<\mathrm{r}$ tabel, maka butir tersebut tidak valid.

Jika $r$ hitung > $r$ tabel tapi negatif, maka butir tersebut tidak valid.

\section{Uji Reliabilitas}

Menurut Arikunto (2006: 178), reliabilitas menunjukkan pada tingkat kevalidan suatu reliabel sehingga dapat dipercaya atau dapat digunakan. Instrumen yang dapat dipercaya akan menghasilkan data yang dapat dipercaya. Apabila data memang benar sesuai dengan kenyataannya, maka berapa kali diambil akan tetap sama.

Pada waktu yang berbeda atau diukur pada orang yang berbeda pada waktu bersamaan tetap memberikan hasil yang sama. Pengujian reliabilitas instrumen dilakukan secara internal, yaitu pengujian reliabilitas dengan teknik Cronbach's Alpha. Teknik ini dilakukan untuk jenis data interval.

Rumus Cronbach's Alpha (Sugiyono, 2009: 265):

$$
r_{11}=\left(\frac{n}{n-1}\right)\left(1-\frac{\sum s_{i}^{2}}{s_{t}^{2}}\right)
$$

$$
\begin{aligned}
& \text { Keterangan: } \\
& \mathrm{r}_{11}=\text { koefisiensi reabilitas tes } \\
& \mathrm{n} \quad=\text { banyak butir item yang dikeluarkan dalam tes } \\
& \sum s_{i}^{2}=\text { jumlah variabel skor dari tiap butir-butir item } \\
& s_{i}^{2}=\text { varians total } \\
& 1 \quad=\text { bilangan konstan } \\
& \sum \mathrm{Si}^{2}=\text { mean kuadrat kesalahan } \\
& \mathrm{Si}^{2}=\text { varians total }
\end{aligned}
$$


Pengujian reliabilitas dalam penelitian ini menggunakan Stastical Package for Social Science (SPSS) 22 for Windows, menggunakan koefisiensi alpha. Menurut Teguh (2003: 25), data yang tidak reliabel dibuang dan diulangi sampai data benar-benar reliabel. Berikut tabel reliabilitas yang disusun berdasarkan Guilford.

Tabel 2. Nilai Reliabilitas

\begin{tabular}{|c|c|c|}
\hline No & Nilai Reliabilitas & Status \\
\hline 1 & $>0,90$ & Sangat Reliabel \\
\hline 2 & $0,70-0,90$ & Reliabel \\
\hline 3 & $0,40-0,70$ & Cukup Reliabel \\
\hline 4 & $0,20-0,40$ & Kurang Reliabel \\
\hline 5 & $<0,20$ & Tidak Reliabel \\
\hline
\end{tabular}

Sumber: Teguh (2003: 25)

\section{Uji Asumsi Klasik}

- Uji normalitas

Menurut Santoso (2005: 212), uji normalitas data menggunakan Kolmogorov-Smirnov Test, dengan membandingkan asymptotic significance dengan $\alpha=5 \%$, dan sebagai dasar penarikan kesimpulan adalah data dikatakan berdistribusi normal apabila nilai asymptotic significance $>0.05$.

- Uji linearitas

Linearitas adalah keadaan di mana hubungan antara variabel terikat dengan variabel bebas bersifat linear (garis lurus) dalam range variabel bebas tertentu. Menurut Sugiarto (dalam Siagian, 2006: 225), untuk memberikan gambaran hubungan dua variabel, sebelum mengetahui apakah hubungan linear atau tidak, sebaiknya dilakukan plotting (tebaran titik) terhadap pasangan nilai-nilai X dan Y. Hasil plot ini disebut dengan diagram pencar (scatter diagram).

Uji linearitas dalam penelitian ini dilakukan dengan menggunakan bantuan SPSS, dan untuk mengetahui apakah terdapat hubungan yang linear bisa dilakukan pemeriksaan sebagai berikut:

1) Dilihat melalui arah titik-titik pada garis lurus. Jika terdapat gejala bahwa titik-titik data itu menyebar di sekitar garis lurus, maka antara kedua variabel terdapat hubungan linear sehingga uji regresi dapat 
dilanjutkan. Sebaliknya jika titik-titik data itu tidak berada di sekitar garis lurus, maka uji regresi tidak dapat dilanjutkan.

2) Dilihat melalui hasil perhitungan menggunakan SPSS. Pada hasil perhitungan dapat dilihat pada tabel anova, yaitu pada kolom signifikansi. Jika nilai signifikansi > 0,05, maka kesimpulannya adalah terdapat hubungan linear secara signifikan antara variabel prediktor $(\mathrm{X})$ dengan variabel kriterium (Y). Sebaliknya, jika nilai signifikansi < 0,05, maka kesimpulannya adalah tidak terdapat hubungan linear antara variabel prediktor (X) dengan variabel kriterium (Y).

\section{Teknik Analisis Data}

Teknik pengolahan data menggunakan perhitungan komputasi program SPSS (Statistical Program for Social Science), yaitu suatu program komputer statistik yang mampu memproses data statistik secara tepat dan cepat menjadi berbagai output yang diinginkan para pengambil keputusan. Menurut Arikunto (2006: 239), analisis data adalah pengolahan data yang diperoleh dengan menggunakan rumus atau dengan aturan-aturan yang ada sesuai pendekatan penelitian.

- Analisis Regresi Linear Sederhana

Regresi linear sederhana merupakan analisis yang dipakai dalam penelitian ini. Menurut Kriyantono (2006:180), analisis digunakan jika terdapat data dua variabel penelitian yang sudah diketahui-yakni variabel bebas (X) dan variabel terikat (Y) — sedangkan nilai Y lainnya dapat dihitung atau diprediksi berdasarkan suatu nilai $X$ tertentu.

Rumus :

$\mathrm{Y}=\mathrm{a}+\mathrm{bX}$

Keterangan :

$\mathrm{Y}=$ Variabel tidak bebas (subjek dalam variabel tidak

bebas/dependen yang diprediksi).

$\mathrm{X}=$ Variabel bebas (subjek pada variabel independen yang mempunyai nilai tertentu).

$\mathrm{A}=$ Nilai intercept $($ konstan) atau harga $\mathrm{Y}$ bila $\mathrm{X}=0$

$\mathrm{b}=$ Koefisiensi regresi, yaitu angka peningkatan atau

penurunan variabel dependen yang didasarkan pada

variabel independen. Bila b (+) maka naik, bila b (-)

maka terjadi penurunan.

Nilai a dihitung dengan menggunakan rumus:

$\mathrm{a}=\frac{\sum \mathrm{Y}\left(\Sigma \mathrm{X}^{2}\right)-\Sigma \mathrm{X} \Sigma \mathrm{Y}}{n \Sigma \mathrm{X}^{2}-\left(\Sigma \mathrm{X}^{2}\right)}$

Nilai b dihitung dengan rumus:

$\mathrm{b}=\frac{\mathrm{n} \sum \mathrm{XY}-\sum \mathrm{X} \sum \mathrm{Y}}{n \sum \mathrm{X}^{2}-\left(\sum \mathrm{X}^{2}\right)}$ 
- Koefisiensi Korelasi

Untuk menguji hubungan variabel bebas dengan variabel terikat dalam penelitian ini, digunakan rumus Pearson Correlations (Product Moment). Menurut Kriyantono (2006:171), rumus atau teknik statistik ini digunakan untuk mengetahui koefisien korelasi atau derajat kekuatan hubungan dan membuktikan hipotesis hubungan antara variabel/data/interval dengan interval lainnya. Berikut adalah rumus Product Moment:

$$
r=\frac{n \cdot \sum X Y-\sum X \cdot \sum Y}{\sqrt{n \cdot \sum X^{2}-\left(\sum X\right)^{2}} \cdot \sqrt{n \cdot \sum Y^{2}-\left(\sum Y\right)^{2}}}
$$

Keterangan:

$$
\begin{array}{ll}
\mathrm{r} & =\text { Koefisien korelasi } \\
\mathrm{n} & =\text { Jumlah sampel } \\
\mathrm{X} & =\text { Nilai variabel } \mathrm{x} \\
\mathrm{Y} & =\text { Nilai variabel } \mathrm{y}
\end{array}
$$

Berikut ini tabel untuk memberi interpretasi terhadap kuatnya hubungan antar-variabel:

Tabel 3. Pedoman untuk Memberikan Interpretasi Koefisien Korelasi

\begin{tabular}{|c|c|}
\hline Interval Koefisien & Tingkat Hubungan \\
\hline $0,00-0,009$ & Sangat Rendah \\
$0,02-0,399$ & Rendah \\
$0,04-0,599$ & Sedang \\
$0,60-0,799$ & Kuat \\
$0,80-0,999$ & Sangat Kuat \\
\hline
\end{tabular}

Sumber: Kriyantono (2006: 171)

- Koefisien Determinasi

Menurut Ghazali (2012: 97), koefisiensi determinasi $\left(\mathrm{R}^{2}\right)$ merupakan alat untuk mengukur seberapa jauh jumlah kemampuan model dalam menerangkan variasi variabel dependen. Nilai koefisiensi determinasi adalah antara nol atau satu. Nilai $\mathrm{R}^{2}$ yang kecil berarti kemampuan variabel independen dalam menjelaskan variasi variabel dependen; memberikan hampir semua informasi yang dibutuhkan untuk memprediksikan variabel dependen.

Rumus koefisiensi determinasi $\left(\mathrm{K}_{\mathrm{d}}\right)$ adalah sebagai berikut (Sugiono, 2012: 231):

$$
K_{d}=r^{2} \times 100 \%
$$


Keterangan :

$\mathrm{K}_{\mathrm{d}}=$ koefisien determinasi

$\mathrm{r}=$ koefisien korelasi

\section{Uji Hipotesis}

Penelitian ini menggunakan uji hipotesis. Data diperoleh dari hasil pengumpulan data di atas dapat diproses sesuai dengan jenis data kemudian disajikan dalam bentuk tabel dan angka metode statistik sebagai berikut:

\section{- Uji F}

Menurut Ghozali (2016: 98), uji F digunakan untuk menilai kelayakan model regresi yang telah terbentuk. Pengujian dilakukan dengan cara membandingkan nilai F tabel dengan F hitung. Dalam menentukan nilai $\mathrm{F}$ tabel, tingkat signifikansi yang digunakan sebesar 5\% dengan derajat kebebasan (df) pembilang $\mathrm{k}=-1$ dan df penyebut $=\mathrm{n}-\mathrm{k}$, dengan $\mathrm{n}$ adalah jumlah responden dan $\mathrm{k}$ adalah jumlah variabel, kriteria pengujian yang digunakan adalah:

Jika F hitung > f tabel, maka $\mathrm{H}_{0}$ ditolak dan $\mathrm{H}_{1}$ diterima, dan

Jika $\mathrm{F}$ hitung < f tabel, maka $\mathrm{H}_{0}$ diterima dan $\mathrm{H}_{1}$ ditolak.

Untuk menguji pengaruh efektivitas absensi finger print terhadap kedisiplinan pegawai digunakan uji $\mathrm{F}$. Menurut Sugiyono (2013: 257), uji F dirumuskan sebagai berikut:

$$
\begin{aligned}
& \text { Keterang } F=\frac{\mathrm{R}^{2}(\mathrm{k}-1)}{1-\mathrm{R}^{2} /(\mathrm{n}-\mathrm{k} 1)} \\
& F=\text { Nilai uji } \mathrm{F} \\
& R^{2}=\text { Koefisien determinasi } \\
& k=\text { Jumlah variabel independen } \\
& \mathrm{n}=\text { Banyak anggota sampel }
\end{aligned}
$$

\section{- Uji t}

Menurut Hartono (2008: 109), besarnya nilai t dijadikan petunjuk untuk mengetahui apakah variabel bebasnya berpengaruh terhadap variabel terikat. Pengujian dilakukan terhadap masing-masing hipotesis dengan pengambilan keputusan: jika nilai sign < 0,05, maka keputusannya $\mathrm{H} 0$ ditolak dan $\mathrm{H} 1$ diterima; atau dengan membandingkan t hitung $>\mathrm{t}$ tabel, maka keputusannya Ho ditolak dan $\mathrm{H} 1$ diterima. 
Rumus : $\quad t=\sqrt{\frac{\mathrm{n}-2}{1-\mathrm{R}^{2}}}$

Keterangan :

$$
\begin{array}{ll}
\mathrm{t} & =\text { nilai } \mathrm{t} \text { hitung } \\
\mathrm{R}^{2} & =\text { nilai } \text { koefisien korelasi } \\
\mathrm{n} & =\text { jumlah sampel }
\end{array}
$$

Jika t hitung > t tabel, maka hubungannya signifikan.

Jika t hitung < t tabel, maka hubungannya tidak signifikan.

Dari hasil t hitung tersebut dibandingkan dengan t tabel. Berdasarkan tingkat kepercayaan 95\%.

Jika thit $\geq \mathrm{t}$ tabel, maka $\mathrm{H}_{0}$ ditolak; artinya secara statistik adalah signifikan, berarti ada pengaruh yang signifikan antara variabel $\mathrm{X}$ dengan variabel $\mathrm{Y}$.

Jika $\mathrm{t}$ hit $\leq \mathrm{t}$ tabel, maka Ho diterima; artinya secara statistik adalah tidak signifikan, berarti $\alpha$ tidak ada pengaruh antara variabel $\mathrm{X}$ dengan variabel $\mathrm{Y}$

\section{HASIL DAN PEMBAHASAN}

Dalam penelitian ini ingin diketahui apakah efektivitas absensi finger print berpengaruh terhadap kedisiplinan pegawai di Kantor Kementerian Agama Kabupaten Bangka.

Dari hasil pengujian validitas variabel efektivitas absensi finger print penelitian yang dicoba kepada 30 responden, diperoleh hasil sebanyak 12 butir pernyataan valid. Untuk $r$ hitung masing-masing $0,706,0,666,0,743,0,903,0,673$, $0,837,0,663,0,856,0,778,0,841,0,862,0,847$ dengan $\mathrm{r}$ tabel $5 \%=0,374$. Artinya tidak ada pernyataan yang dihilangkan, dan tidak ada pula pernyataan yang perlu diganti karena indikator instrumen dinyatakan valid semua.

Adapun hasil pengujian validitas variabel disiplin penelitian yang dicoba kepada 30 responden, diperoleh hasil sebanyak 15 butir pernyataan valid. Untuk $\mathrm{r}$ hitung masing-masing 0,924, 0,913, 0,860, 0,949, 0,755, 0,836, 0,866, 0,823, 0,928, 0,815,
0,843, 0,885, 0,927, 0,883, 0,891 dengan $\mathrm{r}$ tabel $5 \%=0,374$. Artinya, tidak ada pernyataan yang dihilangkan, dan tidak ada pula pernyataan yang perlu diganti karena indikator instrumen dinyatakan valid semua.

Dari hasil pengujian reliabilitas variabel efektivitas absensi finger print diperoleh nilai Cronbach's Alpha sebesar 0,940 dan nilai Cronbach's Alpha if Item Deleted tidak lebih dari

0,940. Dengan melihat kaidah reliabilitas Guilford, maka nilai reliabilitas diketahui.

Dari pengujian reliabilitas variabel efektivitas absensi finger print diperoleh nilai Cronbach's Alpha sebesar 0,977, dan nilai Cronbach's Alpha if Item Deleted lebih dari 0,977 ditemukan satu, yaitu 0,978, sehingga dilakukan pengujian kembali dan diperoleh nilai Cronbach's Alpha sebesar 0,978 dan nilai Cronbach's Alpha if Item Deleted tidak lebih dari 0,978. Dengan 
melihat kaidah reliabilitas Guilford, maka nilai ini reliabel.

Hasil pengujian normalitas ditemukan gambar normal probability plot, menunjukkan bahwa sebaran data pada chart tersebut terdapat korelasi antara expected cumulative probability dengan observerd cumulative probability sehingga memenuhi persyaratan normalitas. Pada gambar berikut ini dapat dilihat bahwa data menyebar di sekitar garis dan mengikuti arah garis diagonal. Dapat disimpulkan bahwa data yang diolah merupakan data yang berdistribusi normal dan model regresi ini layak digunakan.

\section{Gambar 1. Hasil Uji Normalitas P-P Plot}

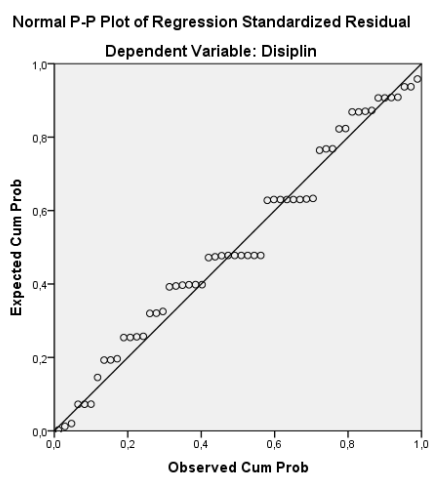

Sumber: Peneliti SPSS 22 (2020)

Dari hasil pengujian linearitas nilai signifikansi deviation from linearity adalah sebesar 0,438 lebih besar dari 0,05. Karena itu, terdapat hubungan yang linear antara Efektivitas Absensi Finger Print dengan Kedisiplinan. Signifikansi nilai signifikansi deviation from linearity sebesar 0,438 lebih besar dari 0,05, sehingga dapat disimpulkan terdapat hubungan linear secara signifikan antara variabel Efektivitas Absensi Finger Print dengan variabel Kedisiplinan.

Dari hasil dari regresi linear sederhana nilai Kedisiplinan Pegawai diperkirakan sebesar 41,268.
Hasil perhitungan koefisien regresi linearitas sederhana dapat dilihat nilai koefisien konstan sebesar 6,128 koefisien dan variabel bebas sebesar 1,004 sehingga diperoleh persamaan regresi $\mathrm{Y}=$ $6,128+1,004 X$. Nilai positif yang terdapat pada koefisien regresi linearitas sederhana variabel Efektivitas Absensi Finger Print menggambarkan bahwa arah hubungan antara efektivitas absensi finger print dengan kedisiplinan pegawai, yakni bahwa setiap kenaikan satu variabel Efektivitas Absensi Finger Print akan menyebabkan kenaikan 1,004. Dengan demikian, nilai Kedisiplinan Pegawai di kantor Kementerian Agama Kabupaten Bangka dapat diperkirakan sebesar 41,268. Hasil ini dapat dijadikan sebagai petunjuk untuk mengetahui apakah variabel Efektivitas Absensi Finger Print berpengaruh terhadap variabel Kedisiplinan Pegawai.

Dari hasil uji koefisien korelasi diketahui bahwa korelasi atau hubungan antara variabel Efektivitas Absensi Finger Print (X) dengan Disiplin Pegawai (Y) sebesar 0,818. Nilai koefisien korelasi sebesar 0,818 masuk dalam range tingkat hubungan yang sangat kuat (berada pada 0,80 0,999).

Mengacu pada tabel pedoman interpretasi terhadap koefisien korelasi, koefisien korelasi antara Efektivitas Absensi Finger Print dan Disiplin Pegawai memiliki hubungan yang sangat kuat karena koefisien korelasi menunjukkan 0,818 yang tergolong pada interval $0,80-0,999$. Korelasi antara $\mathrm{X}$ dan $\mathrm{Y}$ sebesar 0,818 yang artinya terdapat korelasi sangat kuat dan dengan arah positif antara Efektivitas Absensi Finger Print dan Disiplin Pegawai. 
Dari hasil koefisien determinasi ditemukan besaran 0,664, yang berarti pengaruh variabel bebas (independen) terhadap perubahan variabel dependen adalah $66,4 \%$, sedangkan sisanya $33,6 \%(100 \%-$ $66,4 \%$ ) dipengaruhi oleh variabel lain selain kedisiplinan. Hal ini menunjukkan hubungan antara kedua variabel terbilang kuat. Semakin besar angka adjusted $R$ square, semakin kuat hubungan keduanya.

Dari hasil tabel uji F, diperoleh nilai F hitung sebesar 109,539 dengan nilai signifikan 0,000. Hal ini menunjukkan bahwa nilai $\mathrm{F}$ hitung lebih besar dari $\mathrm{F}$ tabel dan nilai signifikansi lebih kecil dari 0,05. Dengan demikian, $\mathrm{H}_{0}$ ditolak dan $\mathrm{H}_{1}$ diterima. Nilai signifikansi sebesar 0,000 sehingga keputusan $\mathrm{H} 0$ ditolak dan $\mathrm{H}_{1}$ diterima. Dengan demikian, keputusannya $\mathrm{H}_{0}$ ditolak dan $\mathrm{H}_{1}$ diterima.

Dari hasil uji $t$ dapat diketahui besar nilai $t$ hitung $=10,466$, sedangkan signifikansi 0,000 lebih kecil dari 0,05 sehingga $\mathrm{H}_{0}$ ditolak dan $\mathrm{H}_{1}$ diterima. Pada nilai $\mathrm{t}$ hitung $=10,466$ lebih besar dari nilai $\mathrm{t}$ tabel = 2,66998 sehingga $\mathrm{H}_{0}$ ditolak dan $\mathrm{H}_{1}$ diterima, yang berarti ada pengaruh yang signifikan antara efektivitas absensi finger print terhadap kedisiplinan pegawai.

\section{Pembahasan}

Rumusan masalah dalam penelitian ini adalah apakah efektivitas absensi finger print berpengaruh terhadap kedisiplinan pegawai di Kantor Kementerian Agama Kabupaten Bangka. Berdasarkan hasil perhitungan dengan menggunakan SPSS versi 22, maka nilai signifikansi sebesar 0,000 sehingga keputusan $\mathrm{H}_{0}$ ditolak dan $\mathrm{H}_{1}$ diterima. Dengan demikian, keputusannya adalah $\mathrm{Ho}$ ditolak dan $\mathrm{H}_{1}$ diterima. Hal ini menunjukkan bahwa efektivitas absensi finger print mempunyai pengaruh yang signifikan terhadap kedisiplinan pegawai di kantor Kementerian Agama Kabupaten Bangka. Jadi, efektivitas absensi finger print yang ada di Kantor Kementerian Agama Kabupaten Bangka memiliki pengaruh yang sangat signifikan terhadap kedisiplinan pegawai. Kedisiplinan pegawai ini perlu senantiasa ditingkatkan agar di kemudian hari kualitas pegawai kian baik dan lebih bertanggung jawab.

Seberapa besar pengaruh efektivitas absensi finger print terhadap kedisiplinan pegawai di Kantor Kementerian Agama Kabupaten Bangka? Berdasarkan hasil perhitungan, diperoleh nilai $R$ Square Adjusted $=0,664$ sehingga besarnya pengaruh efektivitas absensi finger print terhadap kedisiplinan pegawai di Kantor Kementerian Agama Kabupaten Bangka yang dinyatakan dalam nilai koefisien determinasi diperoleh sebesar $66,4 \%$. Hal ini menunjukkan bahwa besar pengaruh efektivitas absensi finger print terhadap kedisiplinan pegawai di Kantor Kementerian Agama Kabupaten Bangka sebesar 66,4\%. Adapun sisanya sebesar $33,6 \%$ dipengaruhi oleh variabel lain di luar penelitian ini.

\section{PENUTUP}

\section{Kesimpulan}

1. Hasil analisis koefisien korelasi dapat dijelaskan bahwa terdapat pengaruh yang signifikan terhadap kedisiplinan pegawai. Dalam hal ini $\mathrm{p}$ value 0,000 lebih kecil dari 0,05 . Besarnya koefisien korelasi adalah 0,818. Besarnya korelasi antara variabel Efektivitas Absensi Finger Print terhadap variabel Disiplin Pegawai, yang ditunjukkan 
dengan angka korelasi 0,818, menunjukkan adanya hubungan yang sangat tinggi. Ini bisa dilihat pada tabel koefisien, yaitu 0,818 berada pada range antara $(0,80$ - 0,999). Adapun persamaan regresinya adalah $\mathrm{Y}=6,128+$ $1,004 X$.

2. Hasil analisis koefisien determinasi dapat diketahui besarnya kontribusi variabel $\mathrm{X}$ terhadap variabel $\mathrm{Y}$ yang ditunjukkan dengan oleh nilai $R$ Square Adjusted, yaitu sebesar 0,664 atau $66,4 \%$. Angka ini menunjukkan bahwa variabel $\mathrm{X}$ yang digunakan dalam persamaan regresi ini mampu memberikan kontribusi terhadap variabel Y sebesar $66,4 \%$, sedangkan sisanya $33,6 \%$ dipengaruhi oleh faktor lain atau variabel di luar penelitian yang diteliti.

3. Berdasarkan tabel uji t untuk menguji hipotesis diketahui besarnya nilai t hitung $=10,466$ lebih besar dari $\mathrm{t}$ tabel $=2,66998$, sedangkan signifikansi 0,000 lebih kecil dari 0,05 sehingga $\mathrm{H}_{0}$ ditolak dan $\mathrm{H}_{1}$ diterima. Hal ini berarti ada pengaruh yang signifikan antara efektivitas absensi finger print terhadap kedisiplinan pegawai. Bagaimana signifikansi pengaruh Efektivitas Absensi Finger Print (X) terhadap Kedisiplinan Pegawai (Y)? Besarnya nilai F hitung 10,539 dengan signifikansi 0,000 atau lebih kecil dari 0,05 sehingga model regresi dapat digunakan dan untuk nilai $\mathrm{F}$ hitung = 109,539 atau lebih besar dari $\mathrm{F}$ tabel $=4,02$. Oleh karena itu, $\mathrm{H}_{0}$ ditolak dan $\mathrm{H}_{1}$ diterima sehingga persamaan regresi dinyatakan baik (good of fit).

4. Dengan demikian, dalam penelitian ini terdapat pengaruh positif dan signifikan variabel
Efektivitas Absensi Finger Print terhadap variabel Kedisiplinan Pegawai yang diberlakukan di Kantor Kementerian Agama Kabupaten Bangka.

\section{Saran}

Berdasarkan hasil kesimpulan yang didapat, peneliti mengajukan beberapa saran dan rekomendasi terkait hasil penelitian, yaitu:

1. Bagi peneliti yang akan datang diharapkan untuk melakukan penelitian lebih lanjut terhadap indikator-indikator lain yang mempengaruhi kedisiplinan pegawai.

2. Efektivitas absensi finger print terhadap kedisiplinan memiliki pengaruh yang sangat tinggi. Untuk itu, peneliti menyarankan agar pegawai selalu menaati peraturan yang telah ditetapkan oleh organisasi ataupun instansi.

3. Peneliti menyarankan kepada Kantor Kementerian Agama Kabupaten Bangka untuk selalu meningkatkan kedisiplinan pegawai dengan selalu memantau, meninjau, dan memperbaiki pelaksanaan sistem absensi yang ada. Selain itu, Kantor Kementerian Agama Kabupaten Bangka hendaknya lebih memperketat pelaksanaan absensi sehingga pegawai tidak bisa pergi dan pulang semaunya.

4. Peneliti menyarankan kepada Kantor Kementerian Agama Kabupaten Bangka untuk berlaku adil dengan memberikan penghargaan bagi pegawai yang selalu datang lebih awal, dan memberikan sanksi bagi pegawai yang melanggar disiplin jam kerja.

\section{DAFTAR PUSTAKA}


Afandi, Pandi. (2018). Manajemen Sumber Daya Manusia. Pekanbaru: Zanafa Publishing

Ahmad, Abu, dan Narbuko, Cholid. (2007). Metodologi Penelitian. Jakarta: Bumi Aksara

Ahmad, Faisal. (2006). "Hubungan Penerapan Absensi Sidik Jari (Finger Print) dengan Motivasi dan Kinerja Karyawan”. Skripsi. Bogor: Fakultas Matematikan dan Ilmu Pengetahuan Alam Institut Pertanian Bogor

Alda, Nela Anggraini. (2014). "Pengaruh Efektivitas Penerapan Absensi Finger Print (Sidik Jari) terhadap Disiplin Kerja Pegawai pada Fakultas Ekonomi dan Ilmu Sosial Universitas Islam Negeri Sultan Syarif Kasim Riau." Skripsi. Pekanbaru: Fakultas Ekonomi dan Ilmu Sosial Universitas Islam Negeri Sultan Syarif Kasim Arikunto, Suharsini. (2006). Prosedur Penelitian Suatu Pendekatan Praktek. Jakarta: Rineka Cipta

Bintoro dan Daryanto. (2017). Manajemen Penilaian Kinerja Karyawan. Yogyakarta: Gava Media

Gandhi, Mohamad Arya. (2017). "Penerapan Absensi Finger Print dalam Mendisiplinkan Kerja Pegawai di Sekolah Menengah Kejuruan (SMK) Sekolah Menengah Teknik Industri (STMI) Bandar Lampung." Skripsi. Lampung: Fakultas Tarbiyah dan Keguruan Universitas Islam Negeri Raden Intan

Gempur, Santoso. (2005). Metodologi Penelitian

Kualitatif dan Kuantitatif. Jakarta: Prestasi Pustaka

Ghozali, Imam. (2016). Aplikasi Analisis Multivariate dengan Program IBM SPSS 23. Semarang: Badan Penerbit Universitas Diponegoro
Hartono, Jogiyanto. (2008). Metodologi Penelitian Sistem Informasi. Yogyakarta: Andi Offset Hasibuan, Malayu S.P. (2014). Manajemen Sumber Daya Manusia. Jakarta: Bumi Aksara

Husein, Umar. (2007). Metode Penelitian untuk Skripsi dan Tesis Bisnis. Jakarta: RajaGrafindo Persada

Indranata, Iskandar. (2008). Pendekatan Kualitatif untuk Pengendalian Kualitas. Jakarta: Universitas Indonesia Press

Kasmir. (2016). Manajemen Sumber Daya Manusia; Teori dan Praktik. Jakarta: RajaGrafindo Persada

Kementerian Agama Republik Indonesia. (2013). Peraturan Menteri Agama Nomor 28 tahun 2013 tentang Disiplin Kehadiran Pegawai Negeri Sipil di Lingkungan Kementerian Agama. Jakarta: Kementerian Agama Republik Indonesia

Kerlinger, Fred N. (2006). Asas-asas Penelitian Behavioral, edisi ke-3. Yogyakarta: Gadjah Mada University Press

Kriyantono, Rachmat. (2006). Teknik Praktis Riset. Jakarta: Kencana Perdana

Kurnia. (2015). "Kementerian Agama Kabupaten Bangka akan Berlakukan Empat Kali Absensi." Diakses dari http://babel.kemenag.go.id/id/berita/307524/

Kementerian-Agama-Kabupaten-BangkaAkan-Berlakukan-Empat-Kali-Absensi pada 23 Januari 2020

Maeyasari, Erna. (2012). "Pengaruh Efektivitas Penerapan Absensi Finger Print terhadap Disiplin Pegawai Negeri Sipil di Sekretariat Daerah Kabupaten Lebak.” Skripsi. Serang: 
Fakultas Ilmu Sosial dan Ilmu Politik Universitas Sultan Ageng Tirtayasa

Mashun, Mohammad. (2006). Pengukuran Kinerja Sektor Publik. Yogyakarta: BPFE UGM

Moenir. (2014). Manajemen Pelayanan Umum di Indonesia. Jakarta: Bumi Aksara

Ruslan, Rosady. (2006). Metode Penelitian Public Relations dan Komunikasi. Jakarta: RajaGrafindo Persada

Sedarmayanti, dan Hidayat, Syarifudin. (2011). Metodologi Penelitian. Bandung: Mandar Maju

Siagian, Sondang P. (2006). Manajemen Sumber Daya Manusia, Jakarta: Bumi Aksara

Sinambela, Lijan Poltak. (2017). Manajemen Sumber Daya Manusia. Jakarta: Bumi Aksara Sugiyono. (2012). Metode Penelitian, Kuantitatif, Kualitatif, dan R\&D. Bandung: Alfabeta

Suyadi. (2010). Rahasia Sidik Jari; Cara Mudah Mendeteksi Bakat dan Kecerdasan Anak dengan Sidik Jari. Yogyakarta: Flash Books

Tangkilisan, Hessel Nogi S. (2005). Manajemen Publik. Jakarta: Gramedia Widiasarana Indonesia

Topik, Moch. (2010). Panduan Praktis Membuat Aplikasi Penggajian dengan MS Office Excel (2007). Jakarta: Mediakita

Zuriah, Nuzul. (2006). Metodologi Penelitian Sosial dan Pendidikan: Teori-Aplikasi. Jakarta: Bumi Aksara 
